\title{
Review
}

\section{Terror and territory: The spatial extent of sovereignty}

\author{
Stuart Elden \\ University of Minnesota Press, Minneapolis, 2009, xxxii + 257pp., \\ $\$ 25.00$ paperback $/ \$ 75.00$ hardback, ISBN: 978-0816654840 \\ Contemporary Political Theory (2012) 11, e10-e13. doi:10.1057/cpt.2010.48
}

Political theorists tend to prioritize the temporal over the spatial. We tend to imagine states of nature before the social contract and the triumph of utopian societies after our contemporary political struggles. But politics does not simply occur between past and future, it also occurs in and over space. And recent work in political geography by scholars such as John Agnew, David Harvey, Bruce Braun and Gearóid O'Tuathail has developed sophisticated theoretical analyses of political space. I am happy to report that Stuart Elden's Terror and Territory is an important addition to this literature, and a work that political theorists working on the concept of sovereignty must read because of its timely analysis of how spatial practices shape contemporary political logics.

Elden's work analyzes the various spatial practices enacted by both the US Government and its various rivals in the Global War on Terror. Although much recent literature on the relationship between territory and terrorism has argued that terrorism represents a de-territorialization of warfare, Elden offers us a more nuanced reading of the War on Terror as simultaneously being involved in practices of de-territorialization and re-territorialization. He looks at the territorial strategies of Islamic groups, and considers the significance of the US Government's insistence on maintaining the territorial integrity of countries such as Iraq and Somalia.

The book begins with the observation that the Latin root of the word territory is unsettled. It could be either terra - referring to land - or terrère - referring to frighten. Elden uses this ambiguity in the etymology of territory to explore how contemporary logics of territory are intertwined with logics of fear. As Elden suggests, if territory does have its root in terrere then territory could mean a place where people are frightened away from, or a space over which fear is exercised. And this definition reflects how - harking back to Weber's definition 
of the state - a monopoly of violence must be exercised over a territory in order for a government to be sovereign.

Chapter 1 looks at various grammars of territory that security analysts have developed since the end of the Cold War. Through close readings of the writings of Francis Fukuyama, Samuel Huntington, Zbigniew Brzezinski, Robert Kaplan and the neo-conservative Project for a New American Century, Elden argues that President George W. Bush's attempt after 9/11 to divide the world into those 'with us' and those 'against us' drew on a pre-existing geographical logic. These early security analysts had already dedicated their writings to dividing the world into safe, stable states in the West and dangerous, 'weak states' in much of the global south. Elden contends that the Bush Administration drew upon this spatial logic in developing its strategy for the War on Terror. He argues that the facile binaries that many of these analysts employ often mask the complex topographies that they claim to represent.

In Chapter 2, Elden turns his analysis to the territorial logic employed by political Islamism. Although conventional wisdom holds Islamic groups such as Al-Qaeda to be de-territorialized networks, Elden contends that Al-Qaeda's strategy has territorial implications. Its strategy involves controlling territory in order to establish bases of operation, and it seeks non-state control of territory by sympathetic actors. Finally, the objectives of many militant Islamic groups are territorial in nature: they involve calling for the withdrawal of Western forces from Islamic countries, and the aspiration to restore the Caliphate in the Middle East. Elden concludes this chapter with the one moment in his analysis that I found unpersuasive. He considers whether or not Agamben's concepts of 'the Camp' and the 'state of exception' are applicable to Al-Qaeda's training camps. Although there have been numerous attempts to link Agamben's work to the Global War on Terror, they have often focused on the US government policies at camps such as Guantanamo Bay, Abu Ghraib and Bagram Airbase. Although Elden, after carefully reconstructing Agamben's arguments, ultimately rejects the analogy, I was left wondering why the analogy was drawn in the first place. Both, Schmitt's and Agamben's concepts of the state of exception explore the tensions between the rule of law and sovereign power, and groups such as Al-Qaeda lack both sovereignty and law, and hence are not capable of creating exceptions to what they do not have.

Chapter 3 focuses on the aspect of the Bush doctrine that focused on target states that harbor terrorists. Elden observes that many 'weak' and 'failed' states involve a fracturing of the relationship between territory and sovereignty. As he persuasively demonstrates, many failed states actually have regions that are stable and well governed - for instance, the Somaliland region of Somalia. Many states are prone to intra-state violence because 
their territorial borders were often fixed by imperial powers before decolonization. These borders often do not reflect the political and national entities within these states, and they have been triggers for subsequent civil wars. However, Western powers are extremely reluctant to resolve these civil and ethnic conflicts by redrawing the borders of states in order to reflect the wishes of the people within them. As such, Elden suggests that many weak and failed states are by-products of the European colonial project, and current US policy in the War on Terror only exacerbates these problems by insisting that states retain their territorial integrity at any cost.

This theme is continued in chapters $4-5$, where Elden explores the spatial strategies behind the invasion of Iraq and the emphasis placed on maintaining territorial integrity in the War on Terror. In these chapters, Elden advances his most persuasive and important insight: that since World War II, the great powers have placed an emphasis on maintaining the territorial integrity of states at all costs. He traces this logic through the Iraq War. During the lead-up to the war, the justification for invading Iraq was to preempt its acquisition of nuclear weapons (a temporal logic) and to integrate its government into the liberal democratic bloc of the west (a spatial logic). Central to these strategies was the insistence that Iraq, despite its complex colonial history and sectarian strife, maintain its territorial integrity. In chapter 5, Elden draws upon his empirical analysis of the Iraq war to argue more generally that as a norm of protecting territorial integrity has strengthened in international law, interventions that violate state sovereignty have increased. Elden correctly points out that most scholars in political science have overlooked this curious tendency. Elden suggests that one possible reason for the emphasis on maintaining territorial integrity while treating sovereignty as contingent is that doing so makes it easier to integrate states into the neo-liberal economic order. As Elden discusses, many of the states that the US Administration targeted in the war on terror - such as Iraq, Iran, Afghanistan and Somalia - were 'rogues' partly because their governments did not participate in the international capitalist system. By keeping states intact, but changing the governing regimes to ones that are willing to integrate into the neo-liberal economic order, it is possible to avoid disputes over property rights and access to mineral resources that normally result from longstanding territorial disputes.

Elden demonstrates convincingly that political theorists - and political scientists more generally - need to spend more time focusing on the role of territory in contemporary politics. He also shows that commonplace claims that Al-Qaeda is a de-territorialized network, or that failed states are sources for terrorism and civil conflict, are not only platitudes, but that they gloss over the complex interaction between sovereignty and territory. As Elden's Terror and Territory shows, sovereignty and territory are not coincident, sovereign

e12 (C) 2012 Macmillan Publishers Ltd. 1470-8914 Contemporary Political Theory Vol. 11, 2, e10-e13 
power must be exercised spatially. Therefore, political theorists interested in sovereignty can find in Elden's work an analysis of how contemporary spatial practices affect the exercise of sovereign power.

Jonathan Havercroft University of Oklahoma, Norman, OK, USA 